\title{
Smart city logistics
}

\author{
Gleb Savin*
}

Ural State University of Economics, 8 Marta Str., 62, 620144 Ekaterinburg, Russia

\begin{abstract}
It can be argued that the scientific paradigm of sustainable development is only partially formed and today there is constant research, searches for the form, and methods of its increment. In the scientific literature (political discussions), this is one of the most used terms due to the wider coverage of the studied areas, as well as a long history in retrospect. But today the most used term is the category of a smart city, which goes beyond the usual discussions about the development of information and communication technologies, and the effective use of information serves as the basis for effective management and functioning of the city. At the same time, logistics expands the possibilities for the formation of a smart city, contributes to economic development, an increase in the quality of human life, the efficiency of the use of economic resources, optimization of flow and non-flow processes, the accumulation of large material, financial, labor and other resources for a competitive practical goal, providing flexibility, adaptability, and competitiveness in conditions for the formation of a digital society.
\end{abstract}

\section{Introduction}

Modern cities as complex and highly organized systems are in constant motion and exhibit complex dynamics, play a key role in social and economic development, and also have a huge impact on the environment. Today they are faced with technical (resource supply, transport, information), social (social and material inequality, security), and environmental problems.

The scientific paradigm of sustainable development is associated with the balanced development of modern cities in all spheres of human life. Digital technologies have caused profound transformations in all types of activities, which prompted significant changes and innovations in the management of socio-economic systems, and this predetermined the development of smart cities.

At the same time, logistics, which serves as a connecting element in the movement of economic resources, is also being transformed under the influence of technology development.

In the era of the digital economy, the management of these systems requires new theoretical and methodological research in the field of harmonization of the stream and non-stream processes in a smart city.

\footnotetext{
* Corresponding author: glebsavin@ya.ru
} 


\section{Materials and Methods}

There are more than 100 cities in the world that claim the title of 'smart' city. At the same time, modern ratings of their assessment (IESE Cities in Motion Index, EasyPark Smart City Index, etc.) reflect the introduction of modern information and communication technologies in human life to improve the quality of his life.

Note that the adopted standards are ISO 37120 Sustainable cities and communities Indicators for city services and quality of life and ISO 37122 Sustainable cities and communities - Indicators for smart cities. cities and communities - Indicators for 'smart' cities), which are focused on the adoption of uniform rules for collecting information, according to which it can be said that the city meets the current standard.

Note that the 'smartness' indicator is a trend that modern cities of the world follow to improve economic, social, and environmental characteristics for sustainable development. The category of 'smart city' and its aspiration for this title, which may, in part, be achievable due to economic and other factors, differ. Based on this, most cities are only on the way to becoming a smart city.

Until now, 'sustainable' city has been the most used term in the scientific literature (political discussions) due to the wider scope of the studied areas, as well as a long history in retrospect [1-5].

Eco-friendly, green, low-carbon suggest the city's environmental objection from different conceptual perspectives [6]. 'Comfortable' is the development of infrastructure for human life, while this definition can be interpreted quite broadly: providing amenities to a given level, which is constantly changing, turns into a process, and can cover all areas.

'Digital', 'informational', 'intelligent', and 'city of knowledge' are also similar definitions, which are united by information as an element of the optimization vision (Table 1). For the first two definitions, its predominance is traced with the help of information and communication technologies, for others, the ability to accumulate and learn to improve the functioning of the city also prevails.

Table 1. Content characteristics of similar categories of the 'smart city' [7, 8]

\begin{tabular}{|c|c|c|c|}
\hline Digital & Intelligent & Smart & Eco-friendly \\
\hline $\begin{array}{l}\text { Informatics } \\
\text { (communication); } \\
\text { City portals for } \\
\text { online } \\
\text { information } \\
\text { services }\end{array}$ & $\begin{array}{l}\text { Intelligent systems; } \\
\text { Online web-based } \\
\text { e-learning systems, } \\
\text { integrated and } \\
\text { compatible with other } \\
\text { city platforms }\end{array}$ & $\begin{array}{c}\text { Quality of life; } \\
\text { Ecology; } \\
\text { E-learning platform and } \\
\text { knowledge management; } \\
\text { Advanced visualization and } \\
\text { simulation tools } \\
\text { benchmarking }\end{array}$ & $\begin{array}{c}\text { Natural } \\
\text { ecosystem; } \\
\text { Economic } \\
\text { development } \\
\text { while protecting } \\
\text { the environment }\end{array}$ \\
\hline
\end{tabular}

The definitions 'smart' and 'sustainable' are associated with balanced development in all areas of socio-economic development. At the same time, a 'sustainable' city operates with a socio-economic and ecological orientation, which has an imbalance of interdependent goals, and along with a 'smart' city, which is focused on 'simplifying' management and optimizing other areas of its functioning using information and communication technologies, and both are aimed at widespread development with the established goals of increasing savings and increasing productivity, reflecting regional (national) specificity and using the best practices and level of technology development in the world.

Today the term 'smart' is gaining the greatest popularity, allowing to ensure the modern functioning of any city, ensuring its sustainability. But if we take into account that sustainability is also a future state that can be predicted and a mechanism for achieving it can be developed, then 'smart' is a certain category of city development, which itself must achieve these predicted states (Table 2-4). 
Table 2. Some well-known definitions of a smart city

\begin{tabular}{|c|c|}
\hline Source & Definition \\
\hline UN & $\begin{array}{l}\text { A city is considered 'smart' if it provides convenience of living, good } \\
\text { transport accessibility, participation of all social groups in the life of the } \\
\text { city, technologies and innovations are effectively used to improve the } \\
\text { quality of life of citizens, coordination and integration of city management }\end{array}$ \\
\hline $\begin{array}{l}\text { The World } \\
\text { Bank }\end{array}$ & $\begin{array}{l}\text { A city that cultivates better relationships between citizens and governments } \\
\text { using available technology. They rely on feedback from citizens to help } \\
\text { improve service delivery and create mechanisms to collect this information }\end{array}$ \\
\hline $\begin{array}{c}\text { European } \\
\text { Innovation } \\
\text { Partnership for } \\
\text { Smart Cities } \\
\text { and } \\
\text { Communities } \\
\end{array}$ & $\begin{array}{l}\text { Where flows and integration are transformed into smart ones by shaping the } \\
\text { strategic use of information and communication infrastructure and services } \\
\text { in the process of transparent urban planning and management that meets the } \\
\text { social and economic needs of society }\end{array}$ \\
\hline $\begin{array}{l}\text { International } \\
\text { Telecommunica } \\
\text { tion Union }\end{array}$ & $\begin{array}{l}\text { An innovative city that uses information and communication technologies } \\
\text { and other means to improve the quality of life, the efficiency of urban } \\
\text { activities, when the needs of the present and future generations correspond } \\
\text { to the economic, social, environmental and cultural development }\end{array}$ \\
\hline $\begin{array}{c}\text { Department of } \\
\text { Enterprise, } \\
\text { Energy and } \\
\text { Industrial } \\
\text { Strategy, UK } \\
\text { (BEIS) }\end{array}$ & $\begin{array}{l}\text { As consumers of private goods and services, we have gained access to the } \\
\text { Internet, and as citizens we expect the same quality from our public } \\
\text { services. In turn, government agencies seek to reduce costs and improve } \\
\text { their efficiency by adopting similar approaches to public service delivery. It } \\
\text { brings together complex infrastructure, social capital, including local skills } \\
\text { and social institutions, and (digital) technology to ensure sustainable } \\
\text { economic development and create an attractive environment for all }\end{array}$ \\
\hline
\end{tabular}

Table 3. Some well-known definitions of a smart city in retrospect

\begin{tabular}{|c|c|}
\hline Author & Definition \\
\hline $\begin{array}{c}\text { Popov E.V., } \\
\text { Semyachkov } \\
\text { K.A. }\end{array}$ & $\begin{array}{c}\text { An innovative city that uses information and communication technologies } \\
\text { and other means to improve the quality of life and efficiency of urban } \\
\text { activities [9] }\end{array}$ \\
\hline $\begin{array}{c}\text { Lövehagen N., } \\
\text { Bondesson A. }\end{array}$ & $\begin{array}{c}\text { Which solves its problems through the strategic use of information and } \\
\text { communication technologies, networks and advanced services to provide } \\
\text { its citizens with intelligent services or opportunities for using intelligent } \\
\text { infrastructure [10] }\end{array}$ \\
\hline Angelidou M. & $\begin{array}{c}\text { City development concept based on the use of human and technological } \\
\text { capital to transform the economy and improve the welfare of residents } \\
{[11]}\end{array}$ \\
\hline Yigitcanlar T. & $\begin{array}{c}\text { Ideal shape for building sustainable cities of the 21st century, subject to } \\
\text { balanced and sustainable views on economic, social, environmental and } \\
\text { institutional development [12] }\end{array}$ \\
\hline
\end{tabular}

Today we can speak of a smart city as a socio-technological system in which the development of technology is consistent with socio-economic and cultural factors $[11,13]$, as well as a social system $[2,4,14]$ and a system of human and relational capital $[6,12$, 15]. It is focused on balanced development and relies on technology in solving social, economic, and environmental problems to improve the quality of life of the population, increase the efficiency of urban management and build up the economic, technological, and intellectual potential of the city [16].

At the same time, a smart city is characterized by social inclusion and the development of the Internet to create new businesses and jobs, to provide high-quality services, and to empower citizens through information, i.e. it is most associated with socio-economic systems. 
Table 4. Definitions of a smart city for corporations and research centers

\begin{tabular}{|c|c|}
\hline Source & Definition \\
\hline Intel & $\begin{array}{c}\text { An urban ecosystem that focuses on leveraging digital technology, shared } \\
\text { knowledge and aligned processes to support citizen benefits in areas such } \\
\text { as mobility, public safety, health and productivity }\end{array}$ \\
\hline Siemens & $\begin{array}{c}\text { Smart city solutions contribute to the efficient management of urban } \\
\text { areas, improving connectivity, resilience, and comfort. In all areas of } \\
\text { urban life, technology and data are used to analyze and optimize, thereby } \\
\text { improving results and quality of life }\end{array}$ \\
\hline BMW & $\begin{array}{c}\text { The digital city of tomorrow with smart initiatives } \\
\text { "System of systems" when the activities of all departments are } \\
\text { coordinated, all information flows into one center, and work with } \\
\text { information available to all departments allows them to optimize their } \\
\text { functioning }\end{array}$ \\
\hline McKinsey & $\begin{array}{c}\text { Cleverness is not just about installing digital interfaces in traditional } \\
\text { infrastructure or optimizing city performance. It is also about the targeted } \\
\text { use of technology and data to make better decisions and a better quality of } \\
\text { life }\end{array}$ \\
$\begin{array}{c}\text { Center for } \\
\text { Regional } \\
\text { Sciences at the } \\
\text { Vienna } \\
\text { University of } \\
\text { Technology }\end{array}$ & $\begin{array}{c}\text { Used to describe a city with a smart industry. This is especially true for } \\
\text { the information and communication technology (ICT) industries, as well } \\
\text { as other industries that use ICT in their production processes. Also for } \\
\text { business parks or own areas of companies. The term 'smart' city is also } \\
\text { used to refer to the education of its inhabitants }\end{array}$ \\
\hline
\end{tabular}

Note that the effective development of the city becomes possible only through the development of new concepts, forms, methods, and principles. To do this, it is necessary to solve the issue of developing the logistics of a smart city, which will most effectively manage the movement of economic resources in the following processes:

- organizations of the city, which have their specific patterns in the advancement of the material flow;

- related to the movement of people (i.e. passenger flows);

- that maintain the current level of functioning of the city;

- which have been and are being carried out at the moment to improve the quality indicators of the city's development.

This is especially important because the information has become an essential component of management, and the use of only a technological approach cannot fully ensure the sustainable development of the city.

The use of systemic, logistic, and optimization approaches will make it possible to single out the logistics of a smart city as a structural unit that ensures the movement of economic resources. At the same time, the intelligent information system will provide the technical and organizational principles of its functioning.

Smart city logistics based on an integrated optimization, system, and logistics approach allows for a comprehensive analysis of flow and non-flow processes.

The optimization approach allows:

1. move from qualitative assessments of the analysis of sustainable development to quantitative ones, thereby expanding the understanding of the deep dependencies and patterns of development and functioning of a smart city;

2. establish correlations between technical, organizational, and economic indicators to develop accurate development forecasts;

3. highlight development priorities, taking into account the current and future impact factors being formed. 
The systematic approach acts as a holistic mechanism that allows you to study all the main elements of the logistics of a smart city and the system itself as a single organism, united by the main flow and non-flow processes, taking into account modernization, technological and time cycles.

The logistics approach expands the tools for analyzing a complex socio-ecological and economic system as a smart city, determines the goal and criteria for evaluating the system, and contributes to the formation of a unified intelligent information system.

As a result, smart city logistics focuses on information flows that provide a better level of management and optimization and increase its competitiveness.

\section{Results and Discussion}

Today, the development of a smart city is focused on the implementation of information and communication technologies by federal and regional programs. Note that these programs are based on current advances in science and technology, depend on technology cycles. To a large extent, they exist in the world within the framework of the information exchange process. The most significant is the mutual influence of information technology, biotechnology, and cognitive science (NBIC convergence).

Let's note the main trends in the development of technologies in the field of forming a smart city using information and communication technologies (IoT, Big Data, artificial intelligence):

- 'green technologies' allow a more responsible approach to the consumption of basic resources (gas, water, $\mathrm{CO}^{2}$ emissions from the introduction of electric transport), develop renewable energy sources;

- widespread introduction of broadband Internet and 5G, which will allow remotely perform various types of work and ensure the development of modern information systems, as well as the development of closed and secure networks;

- control and evaluation of 'dirty data' when used by artificial intelligence in decision-making;

- $\quad$ spread of eSim technology to control the movement of goods from the production process to sale.

In the world today, many corporations (Siemens, BMW, Mercedes Benz, IBM, Phillips, General Electric) are developing their products in the context of a 'smart' city, research centers (IBM, McKinsey or Price Waterhouse) will develop new ideas to fill this methodology with new meanings. Many technologies are aimed at computerization and the development of a digital society.

The key data set of technologies is RIRC: technologies of distributed ledgers (R), artificial intelligence (I), augmented reality (R), and quantum computing (C).

These technologies, combined with the development of appropriate infrastructure, will form a modern intelligent information system of a smart city.

Today, in many cities of the world in the field of information flows, there are no connections between the links of the smart city system, as well as between other participants in order to coordinate flow and non-flow processes, the corresponding infrastructure is not developed. The use of smart city logistics based on an integrated approach will make it possible to develop a concept for the implementation of the main smart city models depending on the population (up to 500, 500-1500, more than 1,500 thousand people), specialization [2], and necessary structural elements, united by a single intelligent information system. This will make it possible to act as the basis for optimization in the field of:

- planned or variable change in the state of economic resources in time, which go through the stages of origin and movement to the destination within the municipality or in transit; 
- discrete and / or periodic concentration of economic resources in order to improve and develop quantitative and qualitative indicators that affect the optimization of flow processes.

\section{Conclusion}

Smart cities are emerging through the intelligent use of digital information $[1,4,6,8,11$, 17], and as the young concept of a 'smart' city in scientific discourse today bypasses a 'sustainable' city, according to $[15,18,19,20]$ it is aimed at sustainable economic development and high quality of life while solving the following tasks:

- sound management of natural resources;

- growth in investment in human and social capital;

- infrastructure development.

A 'smart' city is an effective integration of physical and digital systems for effective and sustainable development and, as an infrastructure project, involves the use of information that allows making decisions on environmental issues, housing and communal services, waste disposal, city economy, renewable energy sources, and also allows you to build a new city management system and form a 'smart' urban environment.

Taking into account the above, the development of the logistics of a smart city is a relevant and necessary tool that ensures sustainable development by a supporting role for industry and the consumer sector, as well as an innovative and industrial role aimed at training personnel, developing necessary technologies, developing infrastructure and hightech industries.

\section{References}

1. V. Albino, U. Berardi, R.M Dangelico, J. of Urban Technology, 1 (2015)

2. M. Benner, European Planning Studies, 9 (2019)

3. E. Ben-Zadok, J. of Urban Affairs, 3 (2019)

4. S. Joss, F. Sengers, D. Schraven, F. Caprotti, Y. Dayot, J. of Urban Technology, 1 (2019)

5. S. Wahba, Smarter cities for an inclusive, resilient future (2019)

6. F. Mneimneh, I. Srour, I. Kaysi, M. Harb, J. of Urban Technology, 1 (2017)

7. M. Jong, S. Joss, D. Schraven, C. Zhan, M. Weijnen, J. of Cleaner Production, 109 (2015)

8. N. Komninos, The age of intelligent cities: environments and innovation-for-all strategies (2014)

9. E.V. Popov, K.A. Semyachkov, Smart Cities, 384 (2020)

10. N. Lövehagen, A. Bondesson, Proceedings of the first international conference on information and communication technologies for sustainability, 2013

11. M. Angelidou, J. of Urban Technology, 4 (2017)

12. T. Yigitcanlar, Technology and the city: systems, applications and implications (2016)

13. G. Grossi, D. Pianezzi, The Int. J. of Urban Policy and Planning, 69 (2017)

14. L. Mora, M. Deakin, A. Reid, Strategic principles for Smart city development: A multiple case study analysis of European best practices. Technological forecasting and social change (2018)

15. A. Caragliu, C. D. Bo, P. Nijkamp, J. of Urban Tech., 2 (2011) 
16. K. V. Gusenova. Economy vector, 32 (2019)

17. Y-Series Recommendations, International Telecommunication Union. Telecommunication Standardization Sector (2017)

18. P. Næss, I.-L. Saglie, T. Richardson, Eu. Planning Studies, 1 (2020)

19. I.J. Ahluwalia, J. of Urban Affairs, 1 (2019)

20. T. Hatuka, I. Rosen-Zvi, M. Birnhack, E. Toch, H. Zur, The political premises of contemporary urban concepts: the global city, the sustainable city, the resilient city, the creative city, and the smart city (2018) 